\title{
Marcin Miotelka
}

Międzyuczelniany Instytut Muzyki Kościelnej w Krakowie

\section{Sprawozdanie z XII Dni Muzyki Kościelnej w Archidiecezji Krakowskiej, 17-21 listopada 2016 r.}

W dniach 17-21 listopada 2016 r. w Archidiecezji Krakowskiej odbyły się XII Dni Muzyki Kościelnej. Honorowy patronat nad festiwalem objął ks. kard. Stanisław Dziwisz - Metropolita Krakowski. Organizatorami wydarzeń muzycznych byli: Archidiecezjalna Komisja Muzyki Kościelnej, Akademia Muzyczna w Krakowie, Uniwersytet Papieski Jana Pawła II w Krakowie, Międzyuczelniany Instytut Muzyki Kościelnej w Krakowie, Archidiecezjalne Szkoła Muzyczna I i II st. im. Kardynała Franciszka Macharskiego w Krakowie, Państwowa Ogólnokształcąca Szkoła Muzyczna II st. im. Fryderyka Chopina w Krakowie, Centrum Edukacji Artystycznej oraz ośrodki kościelne, w których miały miejsce poszczególne koncerty.

Pierwszy, otwierający koncert odbył się 17 listopada o godz. $19.30 \mathrm{w}$ bazylice Mariackiej w Krakowie. Wykonawcami byli studenci oraz pedagodzy Międzyuczelnianego Instytutu Muzyki Kościelnej w Krakowie: Łukasz Mandola (organy w prezbiterium), Paweł Rymarczyk (organy w nawie południowej), dr hab. Witold Zalewski (organy główne), Kinga Brandys-Wójciak (sopran), Anna Stolarczyk (sopran) oraz Chór Międzyuczelnianego Instytutu Muzyki Kościelnej z prof. dr. hab. Wiesławem Delimatem w roli dyrygenta. Repertuar koncertu stanowiły utwory Johanna Pachelbela, Johanna Sebastiana Bacha, Giovanniego Battisty Pergolesiego, Gabriela Faurego, Mikołaja Gomółki, Grzegorza Gerwazego Gorczyckiego, Felixa Mendelssohna-Bartholdy'ego, Williama Byrda oraz Maxa Regera.

W kolejnym dniu festiwalu o godz. 10.00 w budynku Archidiecezjalnej Szkoły Muzycznej oraz Międzyuczelnianego Instytutu Muzyki Kościelnej w Krakowie przy ul. Prostej 35a na organach firmy Schucke odbył się I etap IX Krakowskiego Konkursu Młodych Organistów (współorganizowany przez Centrum Edukacji Artystycznej). W jury konkursu zasiedli: prof. Józef Serafin - przewodniczący, prof. Elżbieta Karolak, prof. Mirosława Semeniuk-Podraza, dr Mieczysław Tuleja oraz dr Marek Wolak. Obowiązki sekretarza jury pełniła mgr Aleksandra Gawlik, zaś za przygotowanie instrumentu w ASM odpowiadał mgr Lech Skoczylas. Tego 
samego dnia, w tym samym miejscu, o godz. 18.00 prof. Elżbieta Karolak dała koncert organowy, podczas którego wykonała utwory Cesara Francka oraz Feliksa Nowowiejskiego.

Następnego dnia, w sobotę 19 listopada, o godz. 10.00 w budynku Państwowej Ogólnokształcącej Szkoły Muzycznej II st. im. Fryderyka Chopina przy ul. Basztowej 6 w sali nr 1 odbył się II etap Krakowskiego Konkursu Młodych Organistów. Jednocześnie przy ul. Prostej 35a oraz w kościele pw. Matki Bożej Dobrej Rady miało miejsce doroczne spotkanie formacyjno-warsztatowe organistów $\mathrm{z}$ archidiecezji krakowskiej. Prowadzącymi zajęcia byli: prof. Wiesław Delimat, mgr Tomasz Kuc, o. dr Dawid Kusz, dr Krzysztof Michałek, dr hab. Włodzimierz Siedlik oraz dr hab. Witold Zalewski. O godz. 17.00 w bazylice Bożego Miłosierdzia w Krakowie-Łagiewnikach odbyły się uroczyste nieszpory chóralne ku czci Chrystusa Króla Wszechświata na zakończenie Roku Miłosierdzia pod przewodnictwem rektora sanktuarium ks. prałata Franciszka Ślusarczyka. Wystąpili: Chór Musica ex Anima z dr. Krzysztofem Michałkiem jako dyrygentem oraz Łukasz Mandola (organy) i Mikołaj Kowalcze (organy). O godz. 19.00 w sali nr 404 Akademii Muzycznej w Krakowie odbył się koncert laureatów IX Krakowskiego Konkursu Młodych Organistów.

W niedzielę 20 listopada o godz. 15.00 w bazylice Bożego Miłosierdzia w Krakowie miała miejsce msza święta oraz uroczystość pobłogosławienia organów w auli im. św. Jana Pawła II. W roli artystów wystąpili: Chór Archidiecezjalnej Szkoły Muzycznej w Krakowie, którym dyrygował prof. dr hab. Wiesław Delimat, Chór Musica ex Anima z dr. Krzysztofem Michałkiem w roli dyrygenta i organisty, Natalia Czuchaj (sopran), Joanna Synowiec (flet), Wojciech Kamionka (waltornia). Tego samego dnia o godz. 19.00 w kościele pw. Najświętszego Serca Pana Jezusa w Brzeźnicy odbył się koncert organowy w wykonaniu uczniów Archidiecezjalnej Szkoły Muzycznej im. ks. kard. Franciszka Macharskiego w Krakowie. Wystąili: Adam Baranowski, Marcin Gawęda, Agnieszka Długosz, Dariusz Samiński oraz Piotr Galon. Zabrzmiały utwory Leona Boellmanna, Johanna Sebastiana Bacha, Maxa Regera, Johanna Pachelbela, Gastona Beliera, Dietricha Buxtehudego oraz Jaques'a-Nicolasa Lemmensa. Niemal w tym samym czasie, o godz. 19.30 w bazylice Mariackiej w Krakowie odbył się koncert chóralny w wykonaniu Chóru Tibi Domine z Justyną Pakulak jako dyrygentem, zaś o godz. 20.00 w kościele pw. Matki Bożej Królowej Polski (Arka Pana) prof. dr hab. Krzysztof Latała dał koncert organowy, w czasie którego można było wysłuchać utworów Johanna Sebastiana Bacha, Oliviera Messiaena i Leona Boellmanna.

$\mathrm{Na}$ koniec XII Dni Muzyki Kościelnej, 21 listopada, o godz. 19.30 w Centrum Jana Pawła II w Krakowie miał miejsce koncert organowy „Z myślą Benedykta XVI” w wykonaniu absolwentów Międzyuczelnianego Instytutu Muzyki 
Kościelnej w Krakowie. Wystąpili: Joanna Oleniak, Dawid Rzepka, Mateusz Peciak. Zabrzmiały utwory Maurica Duruflego, Oliviera Messiaena, Maxa Regera, Louisa Vierna oraz improwizacje w wykonaniu Mateusza Peciaka. 